\title{
ANALISIS TINGKAT KEPATUHAN BENDAHARA PEMERINTAH KABUPATEN SOPPENG DALAM PENYETORAN PAJAK
}

\author{
Nur Fadli*1, Andi Zulfayani \\ Prodi Akuntansi, Universitas Lamappapoleonro Soppeng ${ }^{1,2}$ \\ e-mail: nurfadli.unipol@gmail.com ${ }^{1}$, zulfa.unipol@gmail.com ${ }^{2}$
}

\begin{abstract}
Abstrak
Kontribusi pajak terhadap pembangunan di Indonesia sangat signifikan untuk mendukung roda pemerintahan termasuk pemerintah daerah. Pemungutan pajak melibatkan bendahara pemerintah daerah untuk melakukan perhitungan hingga pelaporan pajak. Penelitian ini bertujuan untuk menganalisis kepatuhan bendahara pemerintah ditinjau dari pemahaman atas self assessment system, kualitas pelayanan, tingkat pendidikan, dan persepsi atas sanksi perpajakan. Penentuan responden menggunakan teknik purposive sampling dengan kriteria yaitu pegawai setiap instansi pemerintah yang berperan sebagai bendahara. Metode penelitian menerapkan penelitian kuantitatif menggunakan model regresi linear. Hasil uji-t menunjukkan adanya pengaruh Pemahaman, Tingkat Pendidikan, dan Sanksi Perpajakan terhadap Kepatuhan Wajib Pajak secara parsial sedangkan Kualitas Pelayanan tidak berpengaruh. Hasil uji-F menunjukkan bahwa keempat variabel independen berpengaruh secara simultan terhadap Kepatuhan Wajib Pajak dengan ketepatan 66,8\% bagian dari kepatuhan wajib pajak bendahara pemerintah di lingkup pemerintah daerah Kabupaten Soppeng sedangkan sisanya dipengaruhi oleh faktor lain yang tidak diteliti.
\end{abstract}

Kata kunci : Kepatuhan bendahara, Bendahara pemerintah, Pajak penghasilan, Penyetoran pajak

\begin{abstract}
The contribution of taxes to development in Indonesia is very significant to support the government activity. Tax collection involves local government treasurers to carry out calculations to tax reporting. This study aimed to analyze the compliance of the government treasurer in terms of understanding the self-assessment system, service quality, education level, and tax sanctions. Determination of respondents using purposive sampling technique with the criteria that employees that acts as treasurer. The research method applies quantitative research using multiple linear regression models. The results of the t-test indicate that there is an effect of understanding, education level, and tax sanctions on taxpayer compliance partially while Service Quality has no effect. The results of the F-test indicate that the independent variables have a simultaneous effect on Taxpayer Compliance with an accuracy of $66.8 \%$ while the rest is influenced by other factors not studied.
\end{abstract}

Keywords : Treasurer compliance, Government treasurers, Income tax, Tax deposit

\section{PENDAHULUAN}

Teori atribusi yang diuraikan Fritz Heider (1958) menjelaskan tentang pemahaman akan reaksi seseorang terhadap peristiwa di sekitar mereka, dengan mengetahui alasanalasan atas kejadian yang dialami. Kepatuhan wajib pajak terkait dengan sikap seseorang dalam membuat penilaian, pemotongan dan pelaporan terhadap pajak itu sendiri sebagai reaksi atas aktivitas keuangan yang telah dilakukan. Sikap tersebut dipengaruhi oleh kondisi internal maupun eksternal seorang wajib pajak (Susilawati \& Budiartha, 2013) dimana sikap patuh seorang bendahara dalam penyetoran dapat dikatakan sebagai bagian internal individu tersebut sementara dukungan pemerintah atau dukungan atasan, 
fasilitas, dan peraturan perundang-undangan yang berlaku merupakan faktor eksternal dari bendahara tersebut yang membawanya pada pengambilan keputusan, ingin patuh atau tidak ingin patuh.

Peningkatan jumlah wajib pajak tidak menjamin terjadinya peningkatan penerimaan pajak. Salah satu faktor yang memengaruhi yaitu peran aktif wajib pajak atau subjek pajak. Untuk memudahkan subjek pajak memenuhi kewajiban perpajakannya maka pemerintah menerapkan self assessment system dan witholding tax system. Self assessment system memungkinkan wajib pajak untuk menjalankan kewajiban pajaknya secara independen sedangkan witholding tax system memberi kesempatan bagi wajib pajak untuk melibatkan pihak ketiga (bukan fiskus dan bukan wajib pajak bersangkutan) dalam menjalankan kewajiban pajak.

Instansi pemerintah sebagai subjek pajak menggunakan with holding tax system dengan melibatkan bendahara sebagai pihak ketiga untuk menentukan besaran pajak yang terutang. Bendahara pemerintah merupakan wajib pajak yang menjadi pihak ketiga yang ditentukan sebagai pemotong dan pemungut pajak oleh Undang-Undang Perpajakan yang diatur dalam UU No.28 tahun 2007 tentang KUP, UU No.36 tahun 2008 tentang Pajak Penghasilan, dan UU No.42 tahun 2009 tentang PPnBM. Bendahara sebagai pejabat fungsional mempunyai tugas untuk menerima dan membayarkan, menatausahakan, serta mempertanggungjawabkan uang untuk keperluan belanja daerah (Permendagri No.13 2006) sehingga bendahara juga melaksanakan pemenuhan kewajiban pajak instansi pemerintah.

Bendahara pengeluaran adalah orang yang ditunjuk untuk menerima, menyimpan, membayar, menatausahakan, dan mempertanggungjawabkan uang untuk keperluan belanja negara dalam rangka pelaksanaan APBN/APBD pada kantor/satuan kerja kementrian negara/lembaga/pemerintah daerah. Bendahara Pengeluaran dibantu oleh Bendahara Pengeluaran Pembantu (BPP) untuk menerima dan menyalurkan dana dari Bendahara Pengeluaran. Tugas BPP adalah membantu Bendahara Pengeluaran untuk melaksanakan pembayaran dan melakukan pembukuan atas seluruh uang yang dikelola.

Bendahara pemerintah sebagai pejabat dalam organisasi pemerintah yang bertanggungjawab dalam pelaporan pajak. Kepatuhan bendahara dalam pelaporan pajak menentukan kesuksesan dalam pelaporan dan penyetoran pajak. Wajib pajak dikatakan patuh pada pasal 1 Peraturan Menteri Keuangan tahun 2007 yaitu (1) tepat waktu dalam penyampaian SPT, (2) tidak mempunyai tunggakan pajak untuk semua jenis pajak, (3) tidak pernah dipidana dalam lima tahun terakhir, (4) melakukan kewajibannya dengan sukarela sesuai peraturan perpajakan yang berlaku di Indonesia. Akan tetapi penerimaan pajak dari belanja APBN dan APBD masih sangat minim khususnya dari belanja APBD yang hanya berkontribusi 3,6\% (Harjowirjono, 2019). Oleh karena itu penelitian mengenai kepatuhan wajib pajak bendahara pemerintah daerah menarik untuk diteliti.

Penelitian Afni (2013) menyimpulkan bahwa pengetahuan perpajakan, pelayanan perpajakan, dan sanksi pajak berpengaruh signifikan terhadap kepatuhan wajib pajak bendahara. Hasil penelitian Setyorini (2015) menyimpulkan bahwa tingkat kepatuhan bendahara dalam pelaporan SPT pajak pertambahan nilai masih rendah dan belum sesuai dengan Undang-undang Nomor 16 tahun 2009 Pasal 4 ayat 1 yang menyebutkan bahwa SPT harus diisi dengan benar, lengkap dan jelas agar tidak menimbulkan sanksi administrasi berupa bunga maupun denda. Hasil penelitian Ahmad (2016) menunjukkan bahwa tingkat kepatuhan bendahara pemerintah dalam penyetoran pajak bervariasi untuk setiap jenis pajak dimana untuk jenis pajak PPN tingkat kepatuhannya sebesar 83\%, pajak 
PPh pasal 21 sebesar 62,5\%, pajak PPh pasal 22 adalah 0\% dan pajak PPh pasal 23 sebesar $82,7 \%$. Tingkat kepatuhan belum menunjukkan $100 \%$ karena penyetoran dilakukan melewati batas waktu penyetoran. Sedangkan tingkat kepatuhan dalam pelaporan pajak 0 atau tidak pernah melaporkan pajak yang disetorkan sebelumnya.

Berdasarkan penjelasan yang telah diuraikan maka penelitian ini bertujuan untuk menganalisis pengaruh pemahaman atas self assessment system, kualitas pelayanan, tingkat pendidikan, dan persepsi atas sanksi perpajakan terhadap kepatuhan wajib pajak (lihat Gambar 1).

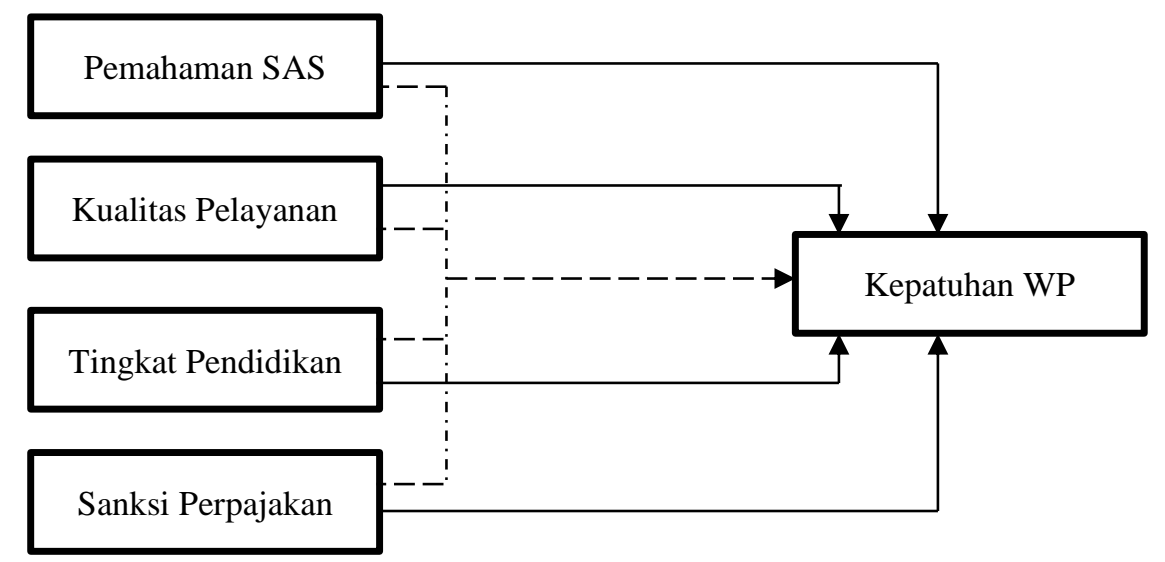

Gambar 1. Kerangka penelitian

Mengacu dari tujuan dan kerangka pikir pada Gambar 1 maka Hipotesis yang diajukan ialah sebagai berikut :

H1 : Terdapat pengaruh Pengetahuan terhadap Kepatuhan Wajib Pajak

H2 : Terdapat pengaruh Kualitas Pelayanan terhadap Kepatuhan Wajib Pajak

H3 : Terdapat pengaruh Tingkat Pendidikan terhadap Kepatuhan Wajib Pajak

H4 : Terdapat pengaruh Sanksi Perpajakan terhadap Kepatuhan Wajib Pajak

H5 : Terdapat pengaruh Pengetahuan, Kualitas Pelayanan, Tingkat Pendidikan, dan Sanksi Perpajakan secara simultan terhadap Kepatuhan Wajib Pajak

\section{METODE PENELITIAN}

Penelitian ini menggunakan pendekatan kuantitatif yang menguji dua variabel dalam penelitian yaitu variabel independen terhadap dependen. Pendekatan kuantitatif bertujuan untuk menyimpulkan dan mengenaralisasi hasil penelitian (Sugiyono, 2013). Penelitian ini akan dilakukan di Organisasi Pemerintahan Daerah/OPD Kabupaten Soppeng yang berjumlah dua puluh tiga terdiri atas dua sekretariat yaitu secretariat daerah dan DPRD, Inspektorat daerah, Lima Badan daerah, dan Sembilan belas dinas serta rumah sakit umum daerah.

Data utama yang digunakan pada penelitian ini yaitu data kuantitatif yang terdiri atas angka. Adapun sumber data penelitian yaitu sumber data primer (data dari responden) dan sumber data sekunder (studi literatur dan data pendukung).

Teknik pengumpulan data pada penelitian ini menggunakan kuesioner. Kuesioner merupakan seperangkat pertanyaan yang telah tersusun secara sistematis mewakili variabel yang ingin diteliti. Kuesioner berisi pertanyaan yang perlu ditanggapi oleh responden. Tanggapan dari responden dianggap mewakil persepsi responden. Pengukuran persepsi responden kemudian di konversi ke bentuk angka menggunakan 
skala likert. Skala likert digunakan untuk mengukur sikap maupun pendapat dan persepsi seseorang terhadap fenomena (Sugiyono, 2013).

Penentuan responden pada penelitian menggunakan teknik purposive sampling yaitu pemilihan responden berdasarkan kriteria yang telah ditentukan peneliti yaitu pegawai yang berperan sebagai bendahara. Berdasarkan hasil pengumpulan informasi awal dan hasil pengumpulan kuesioner maka diperoleh jumlah responden yang sesuai kriteria sebanyak 48 responden.

Pada proses analisis data, peneliti menggunakan alat analisis yaitu SPSS. Pengujian hipotesis penelitian menggunakan model regresi linear berganda dengan persamaan berikut.

Keterangan :

$$
Y=a+b_{1} X_{1}+b_{2} X_{2}+b_{3} X_{3}+b_{4} X_{4}+e
$$

$Y \quad$ : Kepatuhan wajib pajak

a : Konstanta

$b_{1} \ldots b_{4} \quad:$ Koefisien regresi

$X_{1} \quad$ : Pengetahuan

$X_{2} \quad:$ Kualitas pelayanan

$X_{3} \quad$ : Tingkat pendidikan

$X_{4} \quad$ : Sanksi perpajakan

e : Galat

\section{HASIL DAN PEMBAHASAN}

Hasil

Nilai koefisien regresi pada model regresi linear berganda menandakan arah hubungan antara variabel independen dan dependen. Hasil olah data berdasarkan data yang telah dikumpulkan dapat diperhatikan pada tabel berikut

Tabel 1. Koefisien regresi

\begin{tabular}{|c|c|c|c|c|c|c|}
\hline \multicolumn{7}{|c|}{ Coefficients $^{a}$} \\
\hline \multirow{2}{*}{\multicolumn{2}{|c|}{ Model }} & \multicolumn{2}{|c|}{ Unstandardized Coefficients } & \multirow{2}{*}{$\begin{array}{c}\text { Standardized } \\
\text { Coefficients } \\
\text { Beta } \\
\end{array}$} & \multirow[b]{2}{*}{$t$} & \multirow[b]{2}{*}{ Sig. } \\
\hline & & $\mathrm{B}$ & Std. Error & & & \\
\hline \multirow[t]{5}{*}{1} & (Constant) & $-1,502$ & 1,742 & &,- 862 & ,393 \\
\hline & $\mathrm{X} 1$ & ,248 &, 101 & ,250 & 2,445 & 019 \\
\hline & $\mathrm{X} 2$ & ,099 &, 100 & 108 & ,992 & ,327 \\
\hline & X3 & 171 & ,064 & ,244 & 2,698 & , 010 \\
\hline & $\mathrm{X} 4$ &, 578 & , 106 &, 552 & 5,430 &, 000 \\
\hline
\end{tabular}

a. Dependent Variable: $Y$

Sumber : Olah data, 2021

Mengacu pada nilai pada kolom B maka persamaan regresi linear berganda yang akan dibahas pada penelitian yaitu.

$$
Y=-1,502+0,248 X_{1}+0,099 X_{2}+0,171 X_{3}+0,578 X_{4}
$$

Berdasarkan persamaan regresi linear berganda yang diperoleh maka dapat diketahui bahwa ketiga variabel independen menunjukkan arah hubungan positif (+) atau linear. Uraian terkait pengujian hipotesis dengan uji-t diberikan sebagai berikut : 
1. Pada kondisi konstan dimana tidak terdapat perubahan pada koefisien variabel independen maka Kepatuhan Wajib Pajak memiliki nilai -1,502 sehingga dapat diinterpretasikan bahwa dapat terjadi penurunan kepatuhan apabila tidak diberi faktor pendorong namun penurunan kepatuhan tersebut tidak signifikan (Sig. $>\alpha: 0,05)$

2. Nilai thitung yang diperoleh terkait variabel Pengetahuan (X1) sebesar 2,445 dimana nilai tersebut lebih besar dari nilai tabel (dk:43, $\alpha: 0,05)$ yaitu 2,016 serta nilai pada kolom Sig. $(0,019)$ lebih kecil dari tingkat kesalahan yang ditentukan $(\alpha: 0,05)$ sehingga hipotesis pertama $(\mathrm{H} 1)$ diterima bahwa terdapat pengaruh Pengetahuan terhadap Kepatuhan Wajib Pajak. Adapun peningkatan pengetahuan para bendahara pemerintah daerah dapat meningkatkan kepatuhan wajib pajak sebesar 0,248 satuan

3. Nilai thitung yang diperoleh terkait variabel Kualitas Pelayanan (X2) sebesar 0,992 dimana nilai tersebut lebih kecil dari nilai $t_{\text {tabel }}(\mathrm{dk}: 43, \alpha: 0,05)$ sebesar 2,016 dan nilai pada kolom Sig. $(0,327)$ lebih besar dari tingkat kesalahan yang ditolerir yaitu $\alpha=0,05$ sehingga hipotesis kedua $(\mathrm{H} 2)$ ditolak bahwa tidak terdapat pengaruh Kualitas Pelayanan terhadap Kepatuhan Wajib Pajak bendahara pemerintah

4. Nilai thitung yang diperoleh variabel Tingkat Pendidikan (X3) sebesar 2,698 dimana nilai tersebut lebih besar dari nilai $t_{\text {tabel }}(\mathrm{dk}: 43, \alpha: 0,05)$ yaitu 2,016 dan nilai pada kolom Sig. $(0,010)$ lebih kecil dari tingkat kesalahan yang ditentukan yaitu $\alpha=0,05$ sehingga hipotesis ketiga (H3) diterima bahwa terdapat pengaruh Tingkat Pendidikan terhadap Kepatuhan Wajib Pajak. Nilai koefisien menunjukkan bahwa setiap peningkatan pendidikan dapat meningkatkan kepatuhan wajib pajak sebesar 0,171 satuan

5. Nilai $t_{\text {hitung }}$ yang diperoleh variabel Sanksi Perpajakan (X4) sebesar 5,430 dimana nilai tersebut lebih besar dari nilai $\mathrm{t}_{\text {tabel }}(\mathrm{dk}: 43, \alpha: 0,05)$ yaitu $2,016 \mathrm{dan}$ nilai pada kolom Sig. $(0,000)$ lebih kecil dari tingkat kesalahan yang ditentukan yaitu $\alpha=0,05$ sehingga hipotesis keempat (H4) diterima bahwa terdapat pengaruh Sanksi Perpajakan terhadap Kepatuhan Wajib Pajak. Nilai koefisien menunjukkan bahwa setiap peningkatan pendidikan dapat meningkatkan kepatuhan wajib pajak sebesar 0,578 satuan

Hasil uji hipotesis secara parsial menggunakan uji-t menunjukkan bahwa H1, H3, dan $\mathrm{H} 4$ dapat diterima sedangkan $\mathrm{H} 2$ ditolak. Pengujian hipotesis keempat (H5) menggunakan uji-F dapat diperhatikan pada tabel berikut.

Tabel 2. Hasil uji F

\begin{tabular}{|ll|r|r|r|r|r|}
\hline \multicolumn{1}{|c|}{ MNOVA $^{\mathrm{a}}$} & \multicolumn{1}{c|}{ Sig. } \\
\hline 1 & & Sum of Squares & df & Mean Square & F & S \\
& Regression & 88,012 & 4 & 22,003 & 21,673 &, $000^{\mathrm{b}}$ \\
& Residual & 43,655 & 43 & 1,015 & & \\
& Total & 131,667 & 47 & & & \\
\hline
\end{tabular}

a. Dependent Variable: $Y$

b. Predictors: (Constant), X4, X3, X1, X2

Sumber : Olah data, 2021 
Berdasarkan Tabel 2 maka diketahui nilai Fhitung sebesar 21,673 dengan nilai Sig. sebesar 0,000. Mengacu pada kedua nilai tersebut maka dapat disimpulkan bahwa nilai $F_{\text {hitung }}>F_{\text {tabel }}(2,7589)$ dan nilai Sig. $<0,05$ sehingga hipotesis kelima (H5) dapat diterima bahwa terdapat pengaruh Pengetahuan, Kualitas Pelayanan, Tingkat Pendidikan, dan Sanksi Perpajakan kepada Kepatuhan Wajib Pajak secara serentak atau simultan.

Adapun ketepatan keempat variabel tersebut untuk memengaruhi variabel dependen Kepatuhan Wajib Pajak dapat diestimasi berdasarkan nilai R square pada tabel berikut.

Tabel 3. Nilai $R$ square

Model Summaryb

\begin{tabular}{|l|r|r|r|c|}
\hline Model & $\mathrm{R}$ & $\mathrm{R}$ Square & \multicolumn{1}{|c|}{$\begin{array}{c}\text { Adjusted R } \\
\text { Square }\end{array}$} & $\begin{array}{c}\text { Std. Error of the } \\
\text { Estimate }\end{array}$ \\
\hline 1 &, $818^{\mathrm{a}}$ &, 668 &, 638 & 1,00758 \\
\hline
\end{tabular}

a. Predictors: (Constant), X4, X3, X1, X2

b. Dependent Variable: $Y$

Sumber : Olah data, 2021

Nilai $R$ square berdasarkan nilai pangkat dua dari korelasi yaitu sebesar 0,668. Angka tersebut kemudian dikonversi menjadi nilai koefisien determinan sehingga diketahui nilai ketepatan model yaitu 66,8\%. Oleh karena itu dapat diinterpretasikan bahwa faktor Pengetahuan, Kualitas Pelayanan, Tingkat Pendidikan dan Sanksi Perpajakan dapat menjelaskan Kepatuhan Wajib Pajak OPD dengan tingkat ketepatan baik yaitu $66,8 \%$ sedangkan $33,2 \%$ lainnya dipengaruhi oleh faktor lain yang tidak diamati dalam penelitian ini.

\section{Pembahasan}

Pengetahuan seseorang, menurut teori atribusi, dapat menentukan respon seseorang atas kejadian yang dialami. Bendahara pemerintah wajib memiliki pemahaman terhadap regulasi dan sistem yang diterapkan pemerintah untuk pelaksanaan kewajiban perpajakan. Hasil penelitian mengonfirmasi hal tersebut bahwa semakin meningkatnya pengetahuan perpajakan maka dapat meningkatkan kepatuhan wajib pajak secara signifikan.

Pengetahuan perpajakan ialah semua item informasi terkait perpajakan yang dapat membantu wajib pajak dalam memilih tindakan untuk mewujudkan hak bayar dan kewajiban pajaknya (Susilawati \& Budiartha, 2013). Adanya pengetahuan yang cukup maka dapat memudahkan wajib pajak memenuhi kewajiban perpajakannya (Sabila \& Furqon, 2020). Hasil penelitian yang di peroleh sejalan dengan pernyataan sebelumnya bahwa tersedianya pengetahuan terkait tata cara pembayaran pajak maka berdampak signifikan terhadap peningkatan kepatuhan wajib pajak para bendahara di lingkup pemerintah daerah Kabupaten Soppeng.

Bendaharawan pemerintah diharapkan senantiasa meningkatkan pengetahuan terkait perpajakan. Fitrios dan Bonasari (2011) menyampaikan bahwa kepatuhan bendaharawan pemerintah sangat bergantung pada pengetahuan perpajakan dengan catatan bahwa pengetahuan yang dimiliki terkait perpajakan senantiasa ditingkatkan salah satunya melalui bimbingan fiskus saat pelaksanaan kewajiban perpajakan. 
Hasil penelitian terkait hubungan kualitas pelayanan dan kepatuhan wajib pajak menunjukkan bahwa tidak terdapat pengaruh signifikan. Hasil yang diperoleh tidak sejalan dengan temuan Afni (2013) dan Setiawan (2015) bahwa kualitas pelayanan memengaruhi kepatuhan wajib pajak secara signifikan. Akan tetapi hasil tersebut selaras dengan kesimulan Fitrios dan Bonasari (2011) bahwa pelayanan aparat pajak tidak memengaruhi kepatuhan bendaharawan pemerintah serta Ester dkk. (2017) yang menyimpulkan bahwa kualitas pelayanan tidak memengaruhi kepatuhan wajib pajak.

Kualitas pelayanan merupakan bagian dari faktor eksternal, menurut teori atribusi, yang menentukan sikap bendaharawan untuk patuh atau tidak dalam melaksanakan kewajiban perpajakannya. Bagian utama dari kualitas pelayanan perpajakan ialah peran fiskus sebagai pihak pertama yang berhadapan dengan wajib pajak untuk menjelaskan sistematika atau tahap pelaksanaan kewajiban perpajakan (Setiawan, 2015). Bendahara pemerintah secara rutin melakukan kewajiban perpajakannya sesuai tugas yang diberikan sehingga telah memahami alur pelaksanaan kewajiban perpajakan dan tidak lagi bergantung pada fiskus. Responden pada penelitian ini ialah bendahara pemerintah yang berstatus Aparatur Sipil Negara (ASN) dan senantiasa telah diikutkan dalam pelatihan perpajakan sehingga telah memahami fungsi pajak untuk pembangunan. Adanya persepsi tersebut memungkinkan responden untuk tidak bergantung pada kualitas pelayanan dalam melaksanakan kewajiban perpajakannya.

Tingkat pendidikan seseorang, secara konseptual, akan menentukan responnya terhadap suatu permasalahan termasuk perpajakan. Hasil penelitian menunjukkan bahwa tingkat pendidikan berpengaruh signifikan terhadap kepatuhan wajib pajak. Oleh karena itu maka semakin tinggi tingkat pendidikan bendahara maka semakin patuh dalam melaksanakan kewajiban perpajakan. Hal tersebut didasari bahwa semakin tinggi pendidikan maka semakin banyak dan bervariasi pengetahuan yang dimiliki tentang perpajakan (fungsi, tujuan, peran, administrasi) (Ramadhan, 2017) sehingga secara tidak langsung dapat meningkatkan kesadaran dan motivasi untuk menjadi wajib pajak yang patuh terlebih apabila mewakili instansi.

Hasil penelitian sejalan dengan Pauji (2020) yang pada penelitiannya menyimpulkan bahwa tingkat pendidikan berpengaruh positif terhadap kepatuhan wajib pajak dalam membayar pajak. Fitriyani dkk. (2014) pada studinya juga merangkum bahwa kepatuhan wajib pajak pada setiap wajib pajak dengan latar pendidikan berbeda menunjukkan adanya perbedaan signifikan dimana semakin tinggi tingkat pendidikan wajib pajak tersebut maka semakin patuh dalam menjalankan kewajiban pajaknya. Oleh karena itu maka para bendahara pemerintah daerah Kabupaten Soppeng diharapkan dapat meningkatkan pendidikannya agar semakin baik dalam kepatuhan dan pelaksanaan kewajiban perpajakan.

Berbagai upaya pemerintah dalam meningkatkan kepatuhan wajib pajak, salah satunya ialah melalui penerapan sanksi kepada pihak-pihak yang tidak melaksanakan kewajiban pajaknya (Wardhani \& Daljono, 2020). Teori etis Kant mengungkapkan bahwa sanksi merupakan hal yang mutlak ada apabila terjadi pelanggaran. Hal tersebut menunjukkan bahwa sanksi merupakan faktor eksternal, sesuai teori atribusi, yang dapat memengaruhi perilaku wajib pajak. Hasil penelitian mendukung teori tersebut dimana sanksi perpajakan berpengaruh positif terhadap kepatuhan wajib pajak dalam interpretasinya bahwa implementasi penegakan atau pemberian sanksi terhadap wajib 
pajak yang semakin baik (sesuai regulasi) dapat meningkatkan kepatuhan wajib pajak secara signifikan.

Hasil penelitian selaras dengan Afni (2013), Harjowirjono (2019), dan Effendi dkk. (2020) yang menyimpulkan bahwa sanksi perpajakan berpengaruh positif signifikan terhadap kepatuhan wajib pajak. Bendahara pemerintah yang berstatus sebagai ASN tentu tidak ingin memperoleh sanksi sebab apabila melakukan pelanggaran dapat dipecat dari status kepegawaiannya. Kusumo (2009) menuliskan bahwa sanksi bukanlah satu-satunya alat atau pendekatan agar masyarakat menaati hukum namun sanksi merupakan satu-satunya sarana untuk memberi rasa takut kepada orang-orang untuk melakukan kejahatan.

\section{KESIMPULAN}

Berdasarkan hasil dan pembahasan yang telah diuraikan maka terdapat beberapa kesimpulan yang dapat diperoleh yaitu sebagai berikut :

1. Pengetahuan secara parsial berpengaruh signifikan $($ Sig. $<0,05)$ dengan arah korelasi linear terhadap kepatuhan wajib pajak. Temuan tersebut mengindikasikan bahwa adanya peningkatan pengetahuan bendahara pemerintah daerah sangat signifikan untuk meningkatkan kepatuhan wajib pajak

2. Kualitas pelayanan secara parsial tidak berpengaruh signifikan (Sig.>0,05) terhadap kepatuhan wajib pajak. Temuan yang diperoleh mengindikasikan bahwa dalam pelaksanaan kewajiban perpajakannya maka bendahara pemerintah daerah tidak bergantung pada kualitas pelayanan yang diberikan

3. Tingkat pendidikan secara parsial berpengaruh signifikan (Sig.<0,05) dengan arah korelasi positif terhadap kepatuhan wajib pajak. Simpulan tersebut mengindikasikan bahwa semakin tinggi latar pendidikan bendahara pemerintah daerah maka dapat meningkatkan kepatuhannya terhadap kewajiban perpajakan

4. Sanksi perpajakan secara parsial berpengaruh signifikan $($ Sig. $<0,05)$ dengan arah korelasi positif terhadap kepatuhan wajib pajak. Indikasi dari temuan tersebut ialah semakin ketatnya peneraan sanksi perpajakan maka dapat meningkatkan kepatuhan perpajakan bendahara pemerintah daerah

5. Pengetahuan, Kualitas pelayanan, Tingkat pendidikan, dan Sanksi perpajakan berpengaruh secara simultan (Sig. $<0,05)$ terhadap kepatuhan wajib pajak. Untuk meningkatkan penerimaan pajak dari pemerintah daerah maka perlu pendekatan dari berbagai aspek diantaranya yaitu pengetahuan, kualitas pelayanan, tingkat pendidikan, dan sanksi perpajakan yang pada penelitian ini telah terbukti berpengaruh signifikan terhadap kepatuhan wajib pajak

\section{SARAN}

Untuk perbaikan pelaksanaan penelitian pada masa yang akan data maka terdapat beberapa saran yang dapat penulis berikan sebagai berikut :

1. Faktor yang dilibatkan sebagai estimator atau variabel independen pada penelitian ini hanya terbatas pada empat variabel sehingga peneliti selanjutnya dapat menambahkan variabel independen untuk meningkatkan ketepatan prediksi kepatuhan wajib pajak pada periode ke depan 
2. Penelitian ini menggunakan pendekatan kuantitatif yang cenderung kaku sehingga peneliti selanjutnya dapat menerapkan pendekatan berbeda (kualitatif atau mixed method) untuk meneliti kepatuhan wajib pajak agar dapat mengungkap berbagai permasalahan lain terkait kepatuhan wajib pajak yang belum diteliti

3. Responden penelitian tidak dapat ditemui karena adanya pembatasan pertemuan tatap muka pada masa pandemi sehingga disarankan pada peneliti selanjutnya agar sedapat mungkin menemui responden untuk memberi penjelasan

\section{UCAPAN TERIMA KASIH}

Artikel ini tidak terlepas dari bantuan berbagai pihak sehingga Penulis mengucapkan terima kasih kepada Kementerian Pendidikan Kebudayaan Riset dan Teknologi yang telah memberi dukungan financial terhadap penelitian ini.

\section{DAFTAR PUSTAKA}

Afni, Mirwiya. (2013). Faktor-Faktor Yang Mempengaruhi Kepatuhan Wajib Pajak Bendaharawan Pemerintah Di Kabupaten Rokan Hilir. Pekanbaru: UIN

Effendi,A.R. Yuliani, I. Ismatullah, E. Darsawati. (2020). Pengaruh Sanksi Perpajakan terhadap Kepatuhan Wajib Pajak pada KPP Pratama Kota Sukabumi. Syntax Idea, 2(1), 719-725.

Ester, K.G., G.B. Nangoi, S.W. Alexander. (2017). Pengaruh Kualitas Pelayanan Pajak dan Pengetahuan Wajib Pajak terhadap Kepatuhan Wajib Pajak Orang Pribadi di Kelurahan Kleak Kecamatan Malalayang Kota Manado. Jurnal Riset Akuntansi Going Concern, 12(2), 523-530

Fitrios, Ruhul \& P. Bonasari. (2011). Pengaruh Pengetahuan Perpajakan, Pelayanan Perpajakan, dan Sanksi Pajak terhadap Kepatuhan Pajak Bendaharawan Pemerintah Provini Riau. Jurnal Riset Akuntansi dan Bisnis, 11(2), 140-157

Fitriyani, Dewi, E. Prasetyi, R. Yustien, A. Hizazi. (2014). Pengaruh Gender, Latar Belakang Pekerjaan, dan Tingkat Pendidikan terhadap Kepatuhan Wajib Pajak. Jurnal InFestasi, 110(2), 115-122

Harjowirjono, M. (2019). Analisis Faktor-Faktor yang Memengaruhi Kepatuhan Bendahara Pemerintah dalam Penyetoran Pajak. Indonesia Treasury Review, 4(3), 195-217

Heider, Fritz. (1958). The Psychology of Interpresonal Relations. New York : Wiley.

Ismilizar, Ahmad. (2016). Analisis Tingkat Kepatuhan Bendahara Pemerintah dalam Penyetoran Pajak Pada Pemerintah Kabupaten Kerinci. Padang; Univ. Andalas.

Kusumo, B. Ali. (2009). Sanksi Hukum di Bidang Perpajakan. Wacana Hukum, 8(2) : 93106 
Muliari dan Setiawan. (2011). Pengaruh Persepsi tentang Sanksi Perpajakan dan Kesadaran Wajib Pajak pada Kepatuhan Pelaporan Wajib Pajak Orang Pribadi di Kantor Pelayanan Pajak Pratama Denpasar Timur. Jurnal Akuntansi dan Bisnis. 6 (1), 1-23.

Pauji, St. Nuraulia. (2020). Hubungan Tingkat Pendidikan, Kesadaran, Kepercayaan, Pengetahuan Masyarakat terhadap Kepatuhan Wajib Pajak dalam Membayar Pajak. PRISMA, 1(2), 48-58.

Peraturan Menteri Dalam Negeri Nomor 13 tahun 2006 tentang Pedoman Pengelolaan Keuangan Daerah.Undang

Ramadhan, Ranita. (2017). Pengaruh Tingkat Pendidikan dan Sistem Administrasi Perpajakan terhadap Kepatuhan Wajib Pajak Orang Pribadi di KPP Pratama Pare. JIM FEB UB, 5(1), 1-12.

Sabila, N. Sal \& I.K. Furqon. (2020). Pengaruh Pengetahuan Perpajakan, Ketegasan Sanksi Perpajakan, dan Keadilan Perpajakan terhadap Kepatuhan Wajib Pajak UMKM di Kota Pekalongan. Jurnal Akuntansi, Perpajakan, dan Auditing, 1(2), 263-276.

Setyorini, N.L. (2015). Analisis Kepatuhan Bendaharawan Pemerintah Dalam Pelaporan Surat Pemberitahuan Pajak Pertambahan Nilai (Studi Pada Kantor Pelayanan Pajak Pratama Banyuwangi). Jurnal Administrasi Bisnis-Perpajakan (JAB) 5(1), $1-4$.

Sugiyono. (2013). Metode Penelitian (Kuantitatif, Kualitatif, dan R\&D). Bandung : Alfabeta.

Supadmi. (2010). Kepatuhan Memenuhi Kewajiban Pajak Secara Sukarela Merupakan Tulang Punggung dan Self Assesment. E-Journal Unud

Setiawan, Eko Yudi. (2015). Pengaruh Kesadaran Wajib Pajak, Pelayanan Fiskus, dan Sanksi Perpajakan Terhadap Kepatuhan Wajib Pajak UMKM dalam Pelaporan Kewajiban Perpajakan. Tesis. Fakultas Ekonomi UIN Maulana Malik Ibrahim.

Susilawati, K.E. \& I.K. Budiartha. (2013). Pengaruh Kesadaran Wajib Pajak, Pengetahuan Pajak, Sanksi Perpajakan, dan Akuntabilitas Pelayanan Publik pada Kepatuhan Wajib Pajak Kendaraan Bermotor. E-jurnal Akuntansi, 4(2), 345-357

Undang Negara Republik Indonesia Nomor 28 tahun 2007 tentang Ketentuan Umum dan Tata Cara Perpajakan.

Undang Undang Negara Republik Indonesia Nomor 36 tahun 2008 tentang Pajak Penghasilan.

Undang Undang Negara Republik Indonesia Nomor 42 tahun 2009 tentang PPnBM. 
Wahyuni. (2016). Analisis Pemahaman dan Kesadaran Bendahara Pemerintah terhadap Kewajiban Perpajakan. Makassar: UIN Alauddin.

Wardhani, A. Restu \& Daljono. (2020). Pengaruh Pengetahuan Perpajakan, Sosialisasi Perpajakan, dan Sanksi Perpajakan terhadap Kepatuhan Wajib Pajak Badan (Studi terhadap Bendahara Pemerintah pada Badan Pengelola Pendapatan Daerah Provinsi Jawa Tengah). Diponegoro Journal of Accounting, 9(4), 1-9. 